\title{
DAYA HAMBAT ESTRAK ETANOL Caesalpinia sappan L. PADA PERTUMBUHAN Escherichia coli SECARA IN VITRO
}

\author{
Marlina Kamelia ${ }^{1}$, Suharno Zein ${ }^{2}$, dan Reza Fahlida ${ }^{3}$ \\ ${ }^{1}$ Universitas Islam Negeri Raden Intan Lampung \\ 2Universitas Muhammadiyah Metro \\ ${ }^{3}$ Universitas Islam Negeri Raden Intan Lampung
}

\begin{abstract}
Inhibition Of The Ethanol Extract Of Caesalpinia sappan L. In Growth Of Escherichia coli In Vitro
\end{abstract}

Diarrhea is a disease that often affects people in Indonesia. People who experience diarrhea are characterized by the stimulation of bowel movements continuously. This disease is still a major health problem in Indonesian society due to environmental factors and unhealthy living behavior so that food and drinks are contaminated by Escherichia coli bacteria. The form of local wisdom of Indonesian people to deal with diarrhea is by taking traditional medicine. One of the ingredients of traditional medicine that is often consumed is Caesalpinia sappan L. or often known as the secang area. Therefore this study aims to determine the inhibition of ethanol extract of $C$. sappan L. on the growth of $E$. coli in vitro. This type of research is a qualitative experimental method using a Completely Randomized Design (CRD). The treatment in the form of extract concentrations of $0 \%, 20 \%, 40 \%, 60 \%, 80 \%$, and $100 \%$ with 3 repetitions. Inhibition is obtained by measuring the Growth Inhibition Zone (GIZ) after incubation 24 hours and 48 hours. The results of this study indicate that there are significant differences in the inhibition area of each treatment, the higher the concentration of the extract, the inhibitory power increases.

Keywords: Diarrhea, Caesalpinia sappan L., Escherichia coli, Growth Inhibition Zone

\section{Abstrak : Daya Hambat Estrak Etanol Caesalpinia sappan L. Pada Pertumbuhan Escherichia coli Secara In Vitro}

Diare merupakan salah satu penyakit yang sering diderita masyarakat di Indonesia. Orang yang mengalami diare ditandai dengan rangsangan buang air besar secara terus menerus. Penyakit ini masih menjadi masalah kesehatan utama pada masyarakat Indonesia yang disebabkan oleh faktor lingkungan dan perilaku hidup tidak sehat sehingga makanan dan minuman tercemari oleh bakteri Escherichia coli. Bentuk kearifan lokal masyarakat Indonesia untuk mengatasi diare adalah dengan mengonsumsi obat tradisional. Salah satu bahan obat tradisional yang kerap dikonsumsi adalah Caesalpinia sappan L. atau yang sering dikenal dengan nama daerah secang. Oleh karena itu penelitian ini bertujuan untuk mengetahui daya hambat ekstrak etanol $C$. sappan L. terhadap pertumbuhan $E$. coli secara in vitro. Jenis penelitian ini adalah kualitatif dengan metode eksperimen menggunakan Rancangan Acak Lengkap (RAL). Perlakuan pada penelitian berupa konsentrasi ekstrak sebesar $0 \%, 20 \%, 40 \%, 60 \%, 80 \%$, dan $100 \%$ dengan 3 kali pengulangan. Daya hambat didapat dengan mengukur Zona Hambat Pertumbuhan (ZHP) setelah inkubasi 24 jam Dan 48 jam. Hasil penelitian ini menunjukkan terdapat perbedaan yang nyata daerah hambat setiap perlakuan, semakin tinggi konsentrasi ekstrak maka daya hambat semakin meningkat.

Kata Kunci : Diare, Caesalpinia sappan L., Escherichia coli, ZHP 


\section{PENDAHULUAN}

Diare ialah suatu penyakit pada penderita yang mengalami rangsangan buang air besar secara terus menerus. Gejala penyakit ini ditandai dengan sakit perut berlebihan, mulas, pegal pada punggung, badan lesu, dan lemah (Mardjan dan Abrori, 2016). Diare yang berlangsung lama serta tidak disertai penanggulangan medis yang tepat dapat menyebabkan kematian karena kekurangan cairan tubuh. Diare dapat disebabkan oleh makanan atau minuman yang tercemar oleh tinja yang mengandung bakteri atau protozoa penyebab diare.

Pada saat tubuh dalam keadaan sakit, mikroba akan bersifat patogen sehingga menimbulkan berbagai efek samping. Patogenitas mikroba di dalam tubuh dapat disebabkan oleh toksin yang dihasilkan terutama oleh bakteri Escherichia coli dan Salmonella enteritidis (Setiadji, 2009). Gejala klinik diare yang disebabkan kedua bakteri ini adalah konsistensi feses sangat cair, tidak ada darah, nyeri perut terutama daerah umbilikus, kembung, mual, muntah, dan demam ringan (Nurhayati, 2018).

E. coli merupakan golongan Enterobacteriaceae yaitu bakteri gram negatif yang biasanya hidup sebagai flora normal usus kecil dan usus besar yang umumnya tidak menyebabkan penyakit (non-patogenik). Namun, ada juga $E$. coli yang bersifat patogenik antara lain E.coli enteropatogenik (EPEC), E.coli enterounvasif (EIEC), dan E.coli enterotoksigenik (ETEC). Air merupakan pembawa E.coli kelompok ini sehingga keberadaannya pada pangan kemungkinan disebabkan sanitasi pangan yang rendah (Wantik, 2018).

Bakteri yang bersifat patogenik dapat menimbulkan efek samping berbahaya bila tidak tertangani dengan baik. Obat kimiawi yang dapat digunakan untuk mengatasi diare banyak ditemui secara bebas di pasaran. Namun, Indonesia adalah negara dengan banyak sekali kearifan lokal, satu satu kearifan lokal untuk pengobatan diare adalah menggunakan berbagai jenis obat tradisional. Obat tradisional yang banyak dikenal masyarakat untuk mengobati diare antara lain daun jambu biji, rimpang kunyit, buah sirsak, air kelapa, dan juga C. sappan L.. Selain sebagai obat diare, secang (C.sappan L.) dikenal sebagai obat tradisional kaya manfaat seperti antimikroba, antialergi, kaya antioksidan, meningkatkan imun tubuh, mengobati diabetes, dan sebagainya (Mulyani dkk, 2016).

Zat yang terkandung dalam kayu $C$. sappan L. mengandung fenolik, flavonoid, tanin, polifenol, kardenolin, antrakinon, sappan chalcone, caesalpin, resin, resorsin, brazilin, d-alfa phallandren, oscimenen, dan minyak atsiri. Brazilin yang dikandung oleh C.sappan L. berpotensi sebagai antioksidan yang dapat melindungi tubuh dari radikal bebas. Flavonoid, saponin, tanin, polifenol, dan terpenoid mempunyai sifat sebagai antibakteri. Tanin selain bersifat sebagai antibakteri juga bersifat astrigen yang dapat menciutkan dinding usus yang rusak karena asam dan aktivitas bakteri. Penelitian lain menunjukkan bahwa fraksi etanol $C$. sappan $L$. menunjukkan daya antibakteri lebih baik dibandingkan fraksi air C. sappan $L$. terhadap Proteus vulgaris (Karlina dkk, 2016). Fraksi metanol C. sappan L. dapat menghambat pertumbuhan Mycobacterium tubercolosis. Senyawa terpenoid, flavonoid dan antrakinon juga teramati melalui hasil kromatografi lapis tipis (Wardhani, 2012). C. sappan L. memiliki banyak manfaat yang digunakan secara empiris. Oleh karena itu, perlu dilakukan pengujian dengan pendekatan ilmiah. Pengujian daya hambat ekstrak etanol C. sappan $L$. terhadap pertumbuhan bakteri E.coli merupakan penelitian yang dilakukan sebagai sumber informasi bagi penelitian selanjutnya. 
METODE PENELITIAN

Alat

Alat-alat yang digunakan pada penelitian ini yaitu pisau, tampah, blender, timbangan, koran, bejana, batang pengaduk, corong, rotary evaporator, botol steril, alumunium foil, kapas steril, kertas saring diameter $0,6 \mathrm{~cm}$, pipet ukur, gelas ukur, labu erlenmeyer, cawan petri, penjepit tabung reaksi, kawat ose, pinset, inkubator, oven, laminar air flow, autoclave, neraca analitik, hot plate serta magnetik stirer, vortex mixer, bunsen, dan jangka sorong.

\section{Bahan}

Bahan-bahan yang digunakan dalam penelitian ini yaitu kayu C.sappan L., etanol 96\%, kertas saring steril, media Nutrient Agar (NA), biakan murni Escherichia coli ATCC 25922, garam $(\mathrm{NaCl})$ fisiologis, akuades steril, alkohol.

\section{Preparasi Sampel}

Sampel kayu C. sappan L. yang sudah dipilih dicuci sampai bersih lalu dirajang dan dijemur di bawah sinar matahari sampai kering. Sampel kering dibuat menjadi bubuk dengan cara diblender.

\section{Pembuatan Ekstrak Krokot}

Ekstrak kayu C. sappan L. dibuat dengan menggunakan metode maserasi. Maserasi dilakukan menggunakan pelarut etanol $96 \%$. Simplisia sebanyak $500 \mathrm{gr}$ dimasukkan ke dalam bejana kemudian ditambah 2 liter pelarut dan direndam selama 1 hari. Simplisia rendaman diaduk setiap 6 jam, kemudian disaring. Maserat yang dihasilkan kemudian dikumpulkan untuk dipekatkan dengan rotary evaporator hingga didapatkan ekstrak kental.

\section{Pembuatan Larutan Uji}

Larutan uji dibuat dalam rentang konsentrasi yang berbeda antara $20 \%$ sampai $100 \%$. Konsentrasi larutan stok $100 \%$ menggunakan ekstrak kental sebanyak $10 \mathrm{ml}$. Ekstrak kental kayu $C$. sappan L. diencerkan menggunakan akuades untuk memperoleh konsentrasi yang diinginkan. Konsentrasi kelompok perlakuan menggunakan 5 konsentrasi larutan uji yaitu 20\%, 40\%, 60\%, 80\% dan $100 \%$.

\section{Pengenceran dan Inokulasi Bakteri}

Bakteri yang sudah diremajakan diambil 1 ose kemudian dimasukkan ke dalam botol berisi larutan $\mathrm{NaCl}$ fisiologis sebanyak $5 \mathrm{ml}$. Kemudian dihitung kekeruhannya menggunakan standar Mc. Farland. Standar 0,5 Mc Farland setara dengan jumlah bakteri $1,5 \times 10^{8}$ $\mathrm{CFU} / \mathrm{ml}$.

Suspensi bakteri diambil dengan kapas steril. Bakteri yang ada di kapas steril digoreskan ke atas permukaan media yang telah memadat dengan teknik sinambung. Media berisi bakteri diinkubasi selama 24 jam dengan suhu $37^{\circ} \mathrm{C}$.

\section{Uji Aktivitas Antibakteri}

Uji aktivitas antibakteri ekstrak ekstrak kayu C.sappan L. dilakukan dengan menggunakan metode cakram dish. Kertas saring steril direndam dalam 5 konsentrasi ekstrak yang berbeda. Kelima cakram dish tersebut kemudian diletakkan pada permukaan media yang telah mengandung bakteri E. coli. Media diinkubasi pada suhu $37^{\circ} \mathrm{C}$ selama 24 dan 48 jam. Pengamatan dilakukan setelah 24 dan 48 jam dengan mengukur zona hambat yang terbentuk menggunakan jangka sorong dalam satuan milimeter $(\mathrm{mm})$.

\section{Teknik Analisis Data}

Analisis data yang didapatkan dari zona hambat pertumbuhan (ZHP) E.coli menggunakan One Way Anova untuk melihat apakah ada pengaruh perlakuan. Bila terdapat perbedaan pengaruh perlakuan maka diteruskan dengan uji lanjut LSD pada taraf kepercayaan 95\% menggunakan aplikasi SPSS versi 17.0 untuk mengetahui perlakuan mana yang paling mempengaruhi pertumbuhan bakteri E.coli. 
HASIL DAN PEMBAHASAN

\section{Zona Hambat Pertumbuhan (ZHP) Inkubasi 24 Jam}

Berdasarkan hasil penelitian yang telah dilakukan terdapat pengaruh ekstrak pertumbuhan bakteri E.coli seperti tampak pada zona hambat yang tersaji di tabel 1 berikut :

Tabel 1. Zona Hambat Pertumbuhan (ZHP) Inkubasi 24 Jam

\begin{tabular}{lc}
\hline \multicolumn{1}{c}{ Perlakuan } & ZHP \pm SD ( mm ) \\
\hline Konsentrasi $0 \%$ & $0,00^{\mathrm{a}} \pm 0,00$ \\
\hline Konsentrasi $20 \%$ & $6,88^{\mathrm{b}} \pm 0,16$ \\
\hline Konsentrasi $40 \%$ & $7,37^{\mathrm{c}} \pm 0,001$ \\
\hline Konsentrasi $60 \%$ & $7,73^{\mathrm{c}} \pm 0,02$ \\
\hline Konsentrasi $80 \%$ & $8,66^{\mathrm{d}} \pm 0,01$ \\
\hline Konsentrasi $100 \%$ & $11,68^{\mathrm{e}} \pm 0,04$ \\
\hline $\begin{array}{l}\text { Ket : Angka yang diikuti huruf yang sama menunjukkan tidak berbeda nyata pada uji lanjut } \\
\text { LSD dengan taraf kepercayaan } 95 \% .\end{array}$
\end{tabular}

Berdasarkan tabel di atas ratarata tertinggi ZHP pada masa inkubasi 24 jam adalah sebesar 11,64 $\mathrm{mm}$ yaitu pada konsentrasi $100 \%$. Rata-rata terendah ZHP masa inkubasi 24 jam adalah pada kontrol dengan konsentrasi ekstrak $0 \%$ yaitu $0,00 \mathrm{~mm}$. Seluruh perlakuan menunjukkan perbedaan

\section{Zona Hambat Pertumbuhan (ZHP) Inkubasi 48 Jam}

Berdasarkan hasil penelitian yang telah dilakukan terdapat pengaruh ekstrak C.sappan L. terhadap yang nyata dengan kontrol. Perlakuan dengan konsentrasi ekstrak $40 \%$ dan $60 \%$ tidak menunjukkan perbedaan yang nyata berdasarkan uji lanjut LSD pada taraf kepercayaan 95\%. Hasil pengukuran zona hambat pertumbuhan menunjukkan kategori respon penghambatan kuat $(>6 \mathrm{~mm})$.

pertumbuhan bakteri E.coli seperti tampak pada zona hambat yang tersaji di tabel 2 berikut :

Tabel 2. Zona Hambat Pertumbuhan (ZHP) Inkubasi 48 Jam

\begin{tabular}{lc}
\hline \multicolumn{1}{c}{ Perlakuan } & ZHP \pm SD $(\mathbf{m m})$ \\
\hline Konsentrasi $0 \%$ & $0,00^{\mathrm{a}} \pm 0,00$ \\
\hline Konsentrasi $20 \%$ & $8,35^{\mathrm{b}} \pm 0,45$ \\
\hline Konsentrasi $40 \%$ & $8,77^{\mathrm{b}} \pm 0,09$ \\
\hline Konsentrasi $60 \%$ & $10,01^{\mathrm{c}} \pm 0,09$ \\
\hline Konsentrasi $80 \%$ & $10,32^{\mathrm{c}} \pm 0,03$ \\
\hline Konsentrasi $100 \%$ & $12,54^{\mathrm{d}} \pm 0,64$ \\
\hline $\begin{array}{l}\text { Ket : Angka yang diikuti huruf yang sama menunjukkan tidak berbeda nyata pada uji lanjut LSD dengan } \\
\text { taraf kepercayaan } 95 \% .\end{array}$
\end{tabular}

Berdasarkan tabel di atas ratarata tertinggi ZHP pada masa inkubasi 48 jam adalah sebesar $12,54 \mathrm{~mm}$ yaitu pada konsentrasi $100 \%$. Rata-rata terendah ZHP masa inkubasi 48 jam adalah pada kontrol dengan konsentrasi ekstrak $0 \%$ yaitu $0,00 \mathrm{~mm}$. Seluruh perlakuan menunjukkan perbedaan yang nyata dengan kontrol. Perlakuan dengan 
konsentrasi ekstrak $60 \%$ dan $80 \%$ tidak menunjukkan perbedaan yang nyata berdasarkan uji lanjut LSD pada taraf kepercayaan 95\%. Hasil pengukuran zona hambat pertumbuhan menunjukkan kategori respon penghambatan kuat ( $>6 \mathrm{~mm}$ ). Perbandingan ZHP Bakteri E.coli yang diberi ekstrak C. sappan L. masa inkubasi 24 dan 48 jam tampak pada grafik berikut ini :

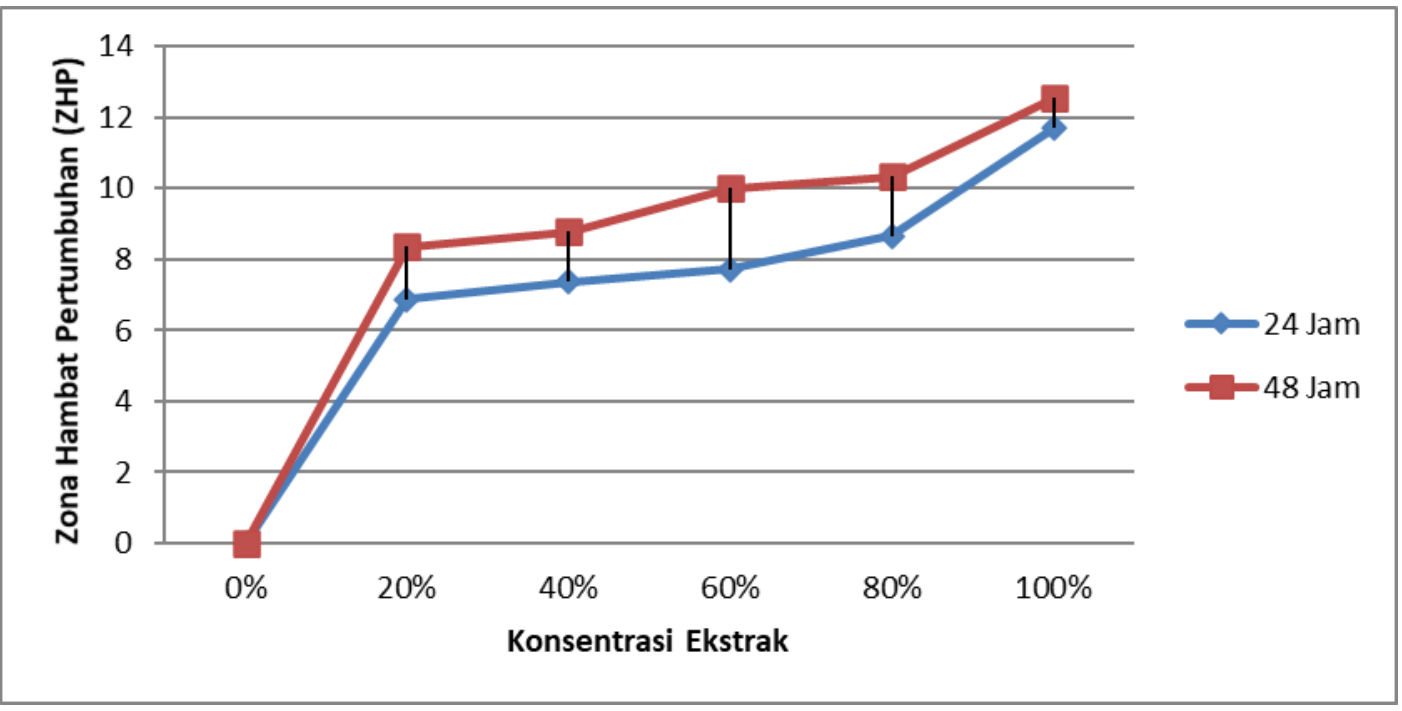

Gambar 1. Grafik Zona Hambat Pertumbuhan Masa Inkubasi 24 Dan 48 Jam

Gambar di atas menunjukkan bahwa semakin lama masa inkubasi diikuti juga dengan peningkatan ZHP E.coli oleh C.sappan L. Hal ini dimungkinkan karena zat aktif yang dihasilkan oleh ekstrak etanol kayu C.sappan L. pada masa inkubasi 24 jam belum menyebar secara merata agar dapat menghambat pertumbuhan bakteri E.coli. Pada masa inkubasi 48 jam zat aktif dari ekstrak etanol kayu C.sapppan L sudah tersebar secara merata di media sehingga penghambatannya terhadap pertumbuhan bakteri E.coli semakin meningkat.

\section{PEMBAHASAN}

Hasil analisis data menunjukkan adanya perbedaan yang nyata antar setiap perlakuan terhadap ZHP bakteri E.coli. Hal ini menunjukkan bahwa ekstrak kayu C.sappan L. memiliki efek antibakteri secara in vitro. Kontrol negatif menggunakan aquades yang seluruhnya menunjukkan nilai ZHP ekstrak etanol C.sappan $L$ sebab fenol
0,00 yang menunjukkan tidak adanya aktivitas antibakteri sehingga dapat dijadikan indikator tidak adanya kontaminasi pada media dan ZHP yang terbentuk pada perlakuan merupakan pengaruh zat aktif dari ekstrak etanol C.sappan L. Zat aktif yang terdapat pada ekstrak kayu C.sappan L. adalah mengandung fenolik, flavonoid, tanin, polifenol, kardenolin, antrakinon, sappan chalcone, caesalpin, resin, resorsin, brazilin, d-alfa phallandren, oscimenen, dan minyak atsiri (Karlina dkk, 2016).

\section{Bakteri E.coli merupakan} bakteri gram negatif mengandung lipoprotein, lipopolisakarida dan lemak pada dinding selnya (Hamidah dkk, 2019). Lapisan-lapisan pada dinding sel pada bakteri tersebut akan sangat terpengaruh oleh aktivitas kerja dari zat antibakteri yang dikeluarkan oleh ekstrak etanol C.sappan L sehingga mempengaruhi pertumbuhan bakteri. Pertumbuhan sel bakteri dapat terganggu oleh komponen fenol dari 
memiliki kemampuan untuk mendenaturasikan protein dan merusak membran sel (Dwyana dan Johannes, 2012).

Selain itu zat-zat aktif yang terkandung dalam ekstrak kayu C.sappan L. seperti tanin, alkaloid, saponin dan flavonoid juga mempengaruhi pertumbuhan bakteri E.coli. Flavonoid dapat menyebabkan kerusakan permeabilitas dinding sel bakteri, mikrosom, dan lisosom akibat adanya interaksi antara flavonoid dengan DNA bakteri (Haryati dan Saleh, 2016). Tanin diduga mampu mengkerutkan dinding sel atau membran sel sehingga permeabilitas sel akan terganggu (Budiwati dkk, 2014).

Saponin bersifat antibakteri karena kemampuannya mengganggu permeabilitas membran sel mikroba sehingga mengakibatkan kerusakan membran sel dan memicu keluarnya berbagai protein, asam nukleat, nukleotida dan lain-lain dari dalam sel (Rahmawati dan Bintari, 2014). Alkaloid sebagai antibakteri memiliki mekanisme penghambatan dengan cara mengganggu komponen penyusun peptidoglikan sehingga lapisan dinding sel tidak terbentuk secara utuh dan menyebabkan kematian sel tersebut (Kurniawan dan Aryana, 2015).

\section{KESIMPULAN}

Hasil penelitian ini dapat disimpulkan bahwa ekstrak etanol kayu Caesalpinia sappan L. memiliki daya hambat terhadap pertumbuhan bakteri E.coli. Konsentrasi ekstrak yang meningkat akan meningkatkan juga kemampuannya dalam menghambat pertumbuhan bakteri $E$. coli secara in vitro. Lama masa inkubasi juga meningkatkan kemampuan ekstrak C.sappan L. dalam menghambat pertumbuhan bakteri E.coli. Daya hambat yang dihasilkan C.sappan masuk dalam kategori kuat (ZHP >6 $\mathrm{mm})$.

\section{SARAN}

Mardjan, H., \& Abrori, M. K. (2016). Pengobatan

Komplementer
Berdasarkan hasil penelitian ini dapat disarankan bahwa: penelitian ini dapat dilanjutkan dengan metode maserasi atau evaporasi, untuk mendapatkan zona hambat bakteri E.coli yang lebih baik serta menguji ekstrak C.sappan L. dengan bakteri gram positif sehingga dapat memastikan keluasan spektrum hambatnya.

\section{DAFTAR PUSTAKA}

Budiwati, A. C., Widodo, G. P., \& Iswandi, I. (2014). Antifungal Activity of n-Hexane, Ethyl Acetate, and Water Fractions from Methanolic Leaves Extract of Mirabilis jalapa L. Against Pityrosporum ovale ATCCÂ® 3179. Jurnal Farmasi Indonesia, 11(1), 75-80.

Dwyana, Z., \& Johannes, E. (2012). Uji Efektivitas Ekstrak Kasar Alga Merah Eucheuma Cottonii Sebagai Antibakteri Terhadap Bakteri Patogen. Jurnal IImu Kefarmasian, $7,1$.

Hamidah, M. N., Rianingsih, L., \& Romadhon, R. (2019). Aktivitas Antibakteri Isolat Bakteri Asam Laktat Dari Peda Dengan Jenis Ikan Berbeda Terhadap E. coli Dan S. aureus. Jurnal IImu dan Teknologi Perikanan, 1(2), 11-21.

Haryati, N. A., \& Saleh, C. (2016). Uji Toksisitas Dan Aktivitas Antibakteri Ekstrak Daun Merah Tanaman Pucuk Merah (Syzygium Myrtifolium Walp.) Terhadap Bakteri Staphylococcus aureus DAN Escherichia coli. Jurnal Kimia Mulawarman, 13(1).

Karlina, Y., Adirestuti, P., Agustini, D. M., Fadhillah, N. L., Fauziyyah, N., \& Malita, D. (2016). Pengujian Potensi Antijamur Ekstrak Air Kayu Secang Terhadap Aspergillus Niger dan Candida Albicans. Chimica et Natura Acta, 4(2), 84-87.

Kurniawan, B., \& Aryana, W. F. (2015). Binahong (Cassia Alata L) As Inhibitor Of Escherichiacoli Growth. Jurnal Majority, 4(4).

Holistik Modern. Mujahid Press Bandung. 
Mulyani, H., Widyastuti, S. H., \& Ekowati, V. I. (2016). Tumbuhan herbal sebagai jamu pengobatan tradisional terhadap penyakit dalam serat Primbon Jampi Jawi jilid I. Jurnal Penelitian Humaniora UNY, 21(2), 124817.

Nurhayati, V. (2018). Asuhan Keperawatan Anak Pada Gangguan Sistem Gastrointestinal: Diare Cair Akut Dengan Dehidrasi Ringan Sampai Sedang Di Rsud Pandan Arang Boyolali (Doctoral dissertation, STIKES Muhammadiyah Klaten).

Rahmawati, F., \& Bintari, S. H. (2014). Studi aktivitas antibakteri sari daun binahong (Anredera cordifolia) terhadap pertumbuhan Bacillus cereus dan Salmonella Enteritidis. Life Science, 3(2).

Setiaji, A. (2009). Uji Aktivitas Antibakteri Ekstrak Petroleum Eter, Etil Asetat Dan Etanol 70\% Rhizoma Binahong (Anredera Cordifolia (Tenore) Steen) Terhadap Staphylococcus aureus Atcc 25923 Dan Escherichia coli Atcc 11229 Serta Skrining Fitokimianya (Doctoral dissertation, Univerversitas Muhammadiyah Surakarta).

Wantik, I. A. A. (2018). Hubungan Personal Higiene Penjamah Dengan Keberadaan Bakteri Coliform Dan Escherichia Coli Pada Es Jeruk Di Pasar Kawak Kelurahan Rejosari Kecamatan Kawedanan Magetan (Doctoral dissertation, STIKES BHAKTI HUSADA MULIA).

Wardani, Y. D. (2012). Aktivitas Antibakteri Ekstrak Etanol Kayu Secang (Caesalpinia sappan L.) Terhadap Staphylococcus aureus ATCC 25923, Shigella sonnei ATCC 9290, Dan Escherichia coli ATCC 25922 (Doctoral dissertation, Universitas Muhammadiyah Surakarta). 